\title{
Hydrogeochemistry and Health Risks Assessment of Some Groundwaters Suitability for Drinking Within the Urban Region of Unguja Island, Zanzibar
}

\author{
Ochieng O. Anthony*, Ali Salim Ali, Hekimani Seif Hamad, Mariam Khamis Hamad, \\ Khamis Abubakar Juma
}

Faculty of Science, Department of Natural Science, Sumait University, Chukwani, Tanzania

\section{Email address:}

d_norbatus@yahoo.com (O. O. Anthony), aboutwalha1995@gmail.com (A. S. Ali), hekmanbinseif@gmail.com (H. S. Hamad), sumait18bc053@gmail.com (M. K. Hamad), abuunurdin2@gmail.com (K. A. Juma)

${ }^{*}$ Corresponding author

\section{To cite this article:}

Ochieng O. Anthony, Ali Salim Ali, Hekimani Seif Hamad, Mariam Khamis Hamad, Khamis Abubakar Juma. Hydrogeochemistry and Health Risks Assessment of Some Groundwaters Suitability for Drinking Within the Urban Region of Unguja Island, Zanzibar. American Journal of Water Science and Engineering. Vol. 7, No. 3, 2021, pp. 113-125. doi: 10.11648/j.ajwse.20210703.13

Received: August 25, 2021; Accepted: September 6, 2021; Published: September 10, 2021

\begin{abstract}
Majority of the Island inhabitants depends on groundwaters for drinking therefore the hydrogeochemistry and health risks assessment with respect to WHO standards is absolutely essential for protection policy formulation. The groundwater samples for analyses were collected from selected four wells within each (Chukwani-Mbweni, DarajaMbovu Amani and Mwanakwerekwe) suburb during the moderate rainy season of January 2020. The selection was based on their strategic positions taking into consideration relevant geographical and environmental factors commensurable with this study. Various contaminants and physiochemical parameters were determined using Atomic Absorption spectroscopy, GC/MS, Temp/pH/TDS/EC meter and DR/3900 spectrophotometer. Chemical Oxygen Demand values were also determined. Microbial contamination was determined using the MPN technique. The results show that these groundwaters are slightly alkaline, microbially contaminated, have high C.O.D. values ranging from 188.5 to $305.7 \mathrm{mg} / \mathrm{L}$ indicating the existence of some organic based endocrine disruptive elements, and disparities in water quality parameters with respect to the recommended WHO standards thus ascertaining possible public health risks. The research recommends the need for continuous monitoring, assessment and treatment of these raw groundwaters for drinking at the point of collection rather relying on the old conventional boiling method or drinking as it is.
\end{abstract}

Keywords: Unguja, Hydrogeochemistry, Ground Waters, Quality Parameters, Endocrine Disruptive Chemicals, Health Risks

\section{Introduction}

Unguja Island of Zanzibar has a current estimated population of 1.8 million with approximately $22 \%$ having access to clean water supplied by Zanzibar Water Authority (ZAWA). This surplus is not sufficient and reliable since at times it is supplied twice a week [38] despite the improvement on palatable groundwater supplies initiated by the help of African Development Bank [1]. Majority rely on drinking either boiled or un-boiled raw groundwater since they cannot afford buying continuously treated bottled water $[81,10]$. Groundwater is regarded as a reliable and resilient water resource for most rural and urban areas of Island of Unguja due to its distributed, subsurface storage and perennial availability as was once reported by $[30,28]$. This Island is surrounded by sea with no fresh water body, thus ground water reserve in Unguja Island is only nourished by seasonal rainfall [8]. Therefore, it is also paramount to have a clear understanding of hydrologic system since it forms the gateway for providing information for the groundwater resource management $[55,83]$ and source for the natural constituents formulating these groundwaters.

Stratigraphically, the Island is shaped by thick sedimentary rocks with a predominating north-south fault direction and 
characterized by Karstic formation, sinkholes and caverns suggesting periods of higher sea level, marine erosion with wave cut cliffs and platforms, reworked marine and fluviatile sediments plus tilting rocking with a raised sea cliffs and submerged coastal reefs [80]. Consequently, the Island surface has only quaternary and tertiary (Miocene) sediments which are mainly sand, cemented sandstone with several forms of limestone weathered coral rock while these thin quaternary deposits covers most of the Miocene soils [68]. The sedimentary formations, in particularly the sand-clay dominated aquifers, have high primary porosity and permeability [33, 22]. This facilitates rapid infiltration and rise of water table after heavy rainfall particularly in the areas where underlying formations are of clayey type [69]. Therefore, this Island poses its delineated ground water resources in terms of lens which float above deeper saline aquifer [29, 39]. The drainage is mainly westerly but also predominantly subsurface except in areas with heavy sticky clay formation.

Lithologically, groundwaters are hosted within either basement (old, crystalline rocks of metamorphic and /or intrusive origin) or sedimentary terrains and the water movements is usually controlled by secondary porosity resulting from chemical weathering, faulting and fracturing $[50,83,90]$ consequently these groundwaters have varying degrees in color and taste though contaminants in groundwater are usually colourless and odourless [73]. These waters are pumped from an aquifer to earth's surface either via a private well or a city water system for use. Excessive groundwater withdrawals lead to water shortage, and decline in the water quality due to saltwater intrusion [37].

Among the marine rocks, metals do exist either in salts of carbonates, chlorides or as hydroxides or in ionic forms depending on the extent of its complexation and oxidation state. Thus, groundwater constituents are the product of natural mechanistic reactions within the geological environment inside an aquifer and are regulated by residence time, flow path, rock type and level of rock-water interaction in addition to evaporation-precipitation [11, 58, 21]. Therefore, most of the inorganic contaminants in groundwater are of geogenic origin as a result of dissolution of the natural mineral deposits within the Earth's crust $[9,60$, $74,32]$. Their concentrations vary from region to region depending on many factors such as the above-mentioned geological structures, soil, water acidity and particulate matter concentration [73, 12, 57]. Consequently, these affects the uniformity of water quality parameters. There are no mining activities on the Island therefore the low $\mathrm{pH}$ associated with acid mine drainage (AMD) which contributes to the solubility of potential toxic metals eventually entering into the groundwaters basin is absent. Therefore, the knowledge of hydrogeochemistry for groundwater is one of the important concepts in assessing the quality of water in Unguja Island.

Apart from the natural geogenic contaminants, potential anthropogenic source of groundwater contamination is domestic sewage especially onsite sanitation systems like pit latrines, cesspits and soak away pits, poor sewage disposal system [43, 64]. The landfills leachates and septic systems, haphazard disposal from agricultural chemicals (e.g. fertilizers, pesticides, etc.), nanoparticles, hydrocarbons, microplastics, underground pipes, road salts, industrial and household cleaning products creates seepage to ground waters $[31,26]$. These contribute to groundwater contamination thus posing threat to human health, ecological services, and sustainable socioeconomic development [47, 48]. These organic and inorganic contaminants are common theme reported in groundwater studies and acts as one of the main sources for lethal endocrine disruptive chemicals (EDC). These EDC are associated with serious health risk such as cancer, sexual hormone imbalances, stomach health issues, brain malfunction, kidney failure, liver cirrhosis [53, $45,40,18]$ consequently they weaken human body immune system [41]. Studies too have shown that physical-chemical components of drinking water have an ability to cause adverse health effects after prolonged periods of exposure and accumulation in our body organs, especially chemicals that have toxic properties and are carcinogenic [52].

Urbanization, agricultural practices, industrial activities, geological disturbances, and climate change all pose significant threats to groundwater quality. Poor sanitations are linked to microbial contaminants which are responsible to transmission of diseases such as cholera, diarrhea, hepatitis A, typhoid and polio. Despite waste waters do get filtered when passing through the soil but microbial contaminants, particularly viruses, do not easily get trapped therefore ground waters needs to be disinfected when used for mass consumption and requires periodical microbial checking.

Despite the use of ground water for drinking may assist in increasing the level of mineral nutrients uptake in the local population, however, it must be also augmented by a nutritious food supply in order to satisfy normal dietary requirements [20]. In 2010, the UN General Assembly explicitly recommended sufficient, safe, acceptable, physically accessible and affordable water for personal and domestic use which must be sustained without causing unacceptable environmental, health, economic or social consequences. Therefore, these raw groundwaters requires regular hydrogeochemistry assessment, protection, and some treatment and purification before they are used for drinking and other domestic purposes [60, 12]. The natural purification processes for contaminated groundwater can take decades or even hundreds of years, even if the source of contamination is cut off $[76,69]$ because it moves slowly and isn't exposed to the natural cleansing benefits of air, sunlight and micro-organism [57]. Once contaminated, remediation is challenging and costly, because groundwater is located in subsurface geological strata, (the wells aren't too deep ranging from 8 to 12 meters in these Unguja regions) and residence times are long $[84,83,73]$.

Therefore, the objectives of this research includes hydrogeochemically assessing groundwater from selected suburbs against the WHO drinking water standards, to determine the contaminants (quantitatively and 
qualitatively), microbial contamination levels, possible health risks and suitable recommendations. The suburbs Chukwani/Mbweni, Daraja Mbovu - Amani and Mwanakwerekwe zones were chosen considering their environmental, geographical (high population, topography, economic, social, poor drainage, perennial waste water reserves, etc.) factors and their strategic positions according groundwater zonation on hydrogeological map of Unguja [29] within the urban center. The groundwater wells chosen are well centralized and point water collections by the majority surrounding communities.

\section{Materials and Methods}

\subsection{The Instruments Used}

Glass-wares used for titrimetric analysis, electronic weighing balance, Temp/pH/TDS/EC meter model MI1399 (cost effective, easy to use and water resistant), Hach DR/3900 Spectrophotometer (multicomponent anion analyzer, easy to operate, robust and fast), Atomic absorption spectroscopy (AAS) is preferred for trace heavy metal ions because of its low cost and short analysis time [85] and Gas chromatographMass spectroscopy (GC-MS) used for identification of hydrocarbon derivatives in the samples, Turbidity meter (Hach 2100HQ, USA). Incubator, test tubes, sterilized plastic bottles, petri-dishes and oven used for microbial essay.

\subsection{The Reagents Used}

The analytical grade reagents includes MacConkey Agar (CM0007), SPADN, APHA, Sodium chloride, Potassium dichromate $\left(\mathrm{K}_{2} \mathrm{Cr}_{2} \mathrm{O}_{7}\right)$, Ferrous ammonium sulphate, Ammonium chloride, Sulphuric acid, etc; Spectroscopic grade reagents e.g. Alcohol, Hexane, Acetonitrile, De-ionized water, etc.; Standard EDTA titrant $(0.01 \mathrm{M})$, Eriochrome black $\mathrm{T}$ indicator, Ferroin indicator, Deionized water, Distilled water ACS grade anions standards and Ammonia buffer solution; HPLC grade reagents include Distilled water, Dichloromethane and Anhydrous Sodium sulfate. Manufacturers are Sigma-Aldrich (USA) and Brüggemann $\mathrm{GmbH} \& \mathrm{Co} . \mathrm{KG}$.

\section{Methods Description}

\subsection{Groundwater Sampling}

The raw groundwater samples were taken from three (3) regions within Unguja Island which are D/Mbovu- Amani, $\mathrm{M} /$ Kwerekwe and C/Mbweni Zones. Samplings were done in the month of January when the region is experiencing moderate rainfall and humid conditions. From each strategically selected well within each zone, three liters of groundwater were taken into sterilized plastic bottles for further analysis. They were transported in a cooler box.

\subsection{Water Preservation}

Sample plastic containers were sterilized according to the laboratory standard sterilization procedures. The sterilized sample bottles were then rinsed three times with the sampled raw ground water before transferring the unfiltered groundwater into the well labeled sterilized 1-liter sample bottles. The unfiltered groundwater samples were preserved at $4{ }^{\circ} \mathrm{C}$ climatic conditions and in sterilized chamber prior to analysis.

\subsection{Physical Parameters Determinations}

The $\mathrm{pH}$, temperature, total dissolved solid (TDS), and electrical conductivity were determined in situ by the portable Temp/pH/TDS/EC multiparameter model MI1399 (cost effective, easy to use and water resistant) according to the manufacturer's instruction The $\mathrm{pH}$ meter was calibrated against $\mathrm{pH}$ buffer of 7,9 and 12. Each reading was taken after 2 minutes taking the precautionary measures after every measurement. In case of turbidity, approximately $25 \mathrm{ml}$ of the sample taken then agitated until all air bubbles disappeared. The quantity was transferred into the sample cell and the turbidity was measured in nephelometric turbidity units (NTU) using turbidity meter (Hach 2100HQ, USA).

\subsection{Anions Determination}

The anions were qualitatively tested using the silver nitrate test to observe the precipitate and anionic constituents confirmed using the Hach DR/3900 split-beam Spectrophotometer $(320-1100 \mathrm{~nm})$ programmed with calibrations for water management test requirements and to counter interferences caused by other chemical species. The method for analysis used was based on standard procedures established by APHA 1998 [7] with each anion having its characteristic wavelength of absorption.

\subsection{Cations Determination}

Samples were digested and analyzed with Atomic Absorption Spectroscopy (Varian Model: AA240) using standard methods established by APHA [7] for metals determination. The digestion procedure was done by carefully adding $5 \mathrm{ml}$ of concentrated nitric acid (anal grad) into $50 \mathrm{ml}$ of water sample on a hot plate for about $30 \mathrm{~min}$ to concentrate the mixture to about $15 \mathrm{ml}$. Approximately $1 \mathrm{ml}$ of the concentrated nitric acid was added periodically to the mixture during the heating processes in the fuming chamber until a clear solution was obtained, cooled, then transferred into $25 \mathrm{ml}$ standard flask and made to the mark using deionized water. Blank samples were prepared using the same procedure for background corrections.

\subsection{Most Probable Number (MPN) Determination for Coliforms}

The most probable number (MPN) analysis is a statistical method based on the random dispersion of microorganisms per volume in a given sample using the multiple tube technique, including the presumptive and confirmatory tests according to established standards (Duksbrough, 2000). In this method, measured volumes of water were added to a 
series of tubes containing a liquid indicator growth medium The media receiving one or more indicator bacteria showed growth and a characteristic colour change. The colour change was absent in those receiving only an inoculum of water without indicator bacteria. From the number and distribution of positive and negative reactions, the MPN of indicator organisms in the sample was estimated with reference to statistical tables. For the confirmatory tests, tubes from the presumptive test were re-incubated for an additional 24 hours at $37^{\circ} \mathrm{C}$, then inoculated onto Eosin methylene blue agar plates using the streaking method and finally the plates were incubated in an inverted position at $37^{\circ} \mathrm{C}$ for 24 hours.

\subsection{Determination for Organic Species Using GC-MS Spectrometry}

GCMS-QP2010 Ultra Shimadzu was used. The MS is merchandised with firmware advanced scanning speed protocol (ASSP) that optimizes the ion transmission hardware parameters with a highly efficient data collection algorithm, acquisition speed up to $20000 \mu / \mathrm{sec}$ and 100HZ, very sensitive. The electron ionization source was kept at the $300^{\circ} \mathrm{C}$. Chromatographic separation was performed using DIOXIN2 column (40m length, internal diameter $180 \mu \mathrm{m}$ and phase thickness $0.18 \mu \mathrm{m}$ with a helium flow of $1 \mathrm{ml} / \mathrm{min}$; The column temperature was programmed starting at $40^{\circ} \mathrm{C}$ - hold for $5 \mathrm{~min}$ - ramp at $10^{\circ} \mathrm{C} / \mathrm{min}$ up to $250^{\circ} \mathrm{C}$ then ramp at $6^{\circ} \mathrm{C}$ upto $330^{\circ} \mathrm{C}$-hold \% min; transfer line temperature- $330^{\circ} \mathrm{C}$. $2 \mu \mathrm{L}$ of sample were introduced into the injector heated at $270^{\circ} \mathrm{C}$ in splitless mode; after $75 \mathrm{~s}$, the injector was purged with a flow of helium at $20 \mathrm{~mL} / \mathrm{min}$. The results were automatically found and quantified using target analyte basing on accurate masses of the molecular ions and certain characteristic fragmented ions as one of the criteria for finding and matching the analytes.

Sample Preparation for the GC-MS machine:

The raw groundwaters from various well in each region were mixed to give a zonal sample and as a result we had three main zonal samples to run. I $\mathrm{ml}$ of groundwater sample was placed in a 5-mL vial, added $1 \mathrm{ml}$ of dichloromethane and shaken for 1 minute. Calculated amount of internal standards $(2-100 \mathrm{ng})$ was added to the organic phase using a syringe, then sodium sulphate approximately $1.5 \mathrm{~g}$ was introduced in portions periodically. After binding of aqueous phase with sodium sulphate, $2 \mu \mathrm{L}$ of the extract was injected into GC in splitless mode.

\subsection{Determination for Chemical Oxygen Demand (COD)}

Chemical Oxygen Demand (COD) this is used to determine the quality of pollution in water. The higher chemical oxygen demand indicates the higher organic pollution in the sample water.

$20 \mathrm{ml}$ of groundwater sample was introduced in a $250 \mathrm{ml}$ round bottom flask added $10 \mathrm{ml}$ of freshly prepared $0.25 \mathrm{~N}$ $\mathrm{K}_{2} \mathrm{Cr}_{2} \mathrm{O}_{7}$, a pinch of $\mathrm{Ag}_{2} \mathrm{SO}_{4}$ and $\mathrm{HgSO}_{4}$ then $20 \mathrm{ml}$ of dil $\mathrm{H}_{2} \mathrm{SO}_{4}$ and finally refluxed for 2.5 hours. The refluxed mixture was then cooled, transferred to a $500 \mathrm{ml}$ conical flask, and diluted to approximately $300 \mathrm{ml}$ by distilled water, then added 3 drops of ferroin indicator and titrated against freshly prepared $0.25 \mathrm{~N}$ Mohr's salt till the endpoint of winered color achieved. Let the titre value be $\mathrm{X} \mathrm{ml}$.

Blank titration was performed using distilled water in place of sample solution and refluxed for the same time then titrated against the $0.25 \mathrm{~N}$ Mohr's salt. Let the titre value be Y ml.

Calculations:

$$
\text { C. O. D in mg/litre }=\frac{(\mathrm{Y}-\mathrm{X}) \times \mathrm{N} \text { of Mohr's salt } \times 1000 \times 8}{\text { Volume of ground water sample }}
$$

\subsection{Determination of Hardness}

$50 \mathrm{ml}$ of the groundwater sample was taken into a conical flask, added $1 \mathrm{ml}$ of buffer solution then $5 \% \mathrm{Na}_{2} \mathrm{~S}$ solution. To the mixture was added approximately $150 \mathrm{mg}$ of Eriochrome black T-Nacl mixture and swirled till the sample solution turned wine red. The content was then titrated with EDTA solution until blue coloration is obtained signifying the end point.

Calculation:

Hardness, mg of $\mathrm{CaCo}_{3} /$ liter $=\frac{\mathrm{ml} \text { of } 0.01 \mathrm{M} \text { EDTA used } \times 1000}{\text { Volume of ground water sample }}$

1000 cc $1 \mathrm{M}$ EDTA $\equiv 1000 \mathrm{~g} \mathrm{CaCO}_{3}$

$1 \mathrm{ml} 0.01 \mathrm{M}$ EDTA $\equiv 1 \mathrm{mg}$ of $\mathrm{CaCO}_{3}$

\subsection{Data Analysis}

Data obtained were subjected to statistical analysis and reported on the basis of mean deviation.

\section{Results}

The concentrations for cation parameter using the Atomic Absorption spectrophotometer are shown in table 1 below in comparable with the W.H.O. guideline values for drinking water.

Table 1. Cations Concentrations.

\begin{tabular}{lllll}
\hline Parameter & C/Mbweni Zone $\mathbf{~ m g / L}$ & D/Mbovu-Amani Zone $\mathbf{~ m g / L}$ & M/Kwerekwe Zone mg/L & W.H.O. Limit values mg/L \\
\hline $\mathrm{Cd}$ & $0.01 \pm 0.02$ & $0.01 \pm 0.03$ & $0.02 \pm 0.01$ \\
$\mathrm{Mg}$ & $140.1 \pm 0.25$ & $72.2 \pm 0.05$ & $138.3 \pm 0.02$ \\
$\mathrm{Mn}$ & $0.15 \pm 0.01$ & $0.19 \pm 0.01$ & $0.16 \pm 0.01$ & 0.003 \\
$\mathrm{Na}$ & $245.5 \pm 0.00$ & $156.26 \pm 0.04$ & $210.3 \pm 0.02$ & 0.1 \\
$\mathrm{~Pb}$ & - & $0.24 \pm 0.00$ & - & 200 \\
$\mathrm{Zn}$ & - & - & $0.02 \pm 0.00$ & 0.01 \\
$\mathrm{Fe}$ & $0.07 \pm 0.01$ & $0.09 \pm 0.02$ & $0.051 \pm 0.00$ & 3.0 \\
$\mathrm{Cu}$ & $0.022 \pm 0.00$ & $0.085 \pm 0.01$ & $34.99 \pm 0.02$ \\
$\mathrm{~K}$ & $43.83 \pm 0.01$ & $11.53 \pm 0.02$ & & 0.03 \\
\hline
\end{tabular}




\begin{tabular}{lllll}
\hline Parameter & C/Mbweni Zone $\mathbf{~ m g / L}$ & D/Mbovu-Amani Zone $\mathbf{~ m g / L}$ & M/Kwerekwe Zone $\mathbf{~ m g / L}$ & W.H.O. Limit values mg/L \\
\hline $\mathrm{Ca}$ & $223.67 \pm 0.02$ & $251.39 \pm 0.04$ & $333.12 \pm 0.01$ & 200 \\
$\mathrm{Al}$ & $0.21 \pm 0.01$ & $0.88 \pm 0.01$ & $0.92 \pm 0.01$ & 0.2 \\
$\mathrm{Cr}$ & $0.01 \pm 0.00$ & $0.02 \pm 0.00$ & $0.01 \pm 0.01$ & 0.05 \\
$\mathrm{Se}$ & $0.02 \pm 0.01$ & $0.01 \pm 0.02$ & $0.01 \pm 0.00$ & 0.01 \\
$\mathrm{As}$ & $0.02 \pm 0.00$ & $0.05 \pm 0.01$ & $0.03 \pm 0.01$ & 0.05 \\
\hline
\end{tabular}

The anions were qualitatively tested using the silver nitrate test and precipitates were obtained. The results for anionic constituents with their concentrations confirmed using the Hach DR/3900 split-beam Spectrophotometer (320 - $1100 \mathrm{~nm})$ are shown in table 2 below.

Table 2. Anions Concentrations.

\begin{tabular}{|c|c|c|c|c|}
\hline Parameter & C/Mbweni Zone mg/L & D/Mbovu -Amani mg/L & M/Kwerekwe mg/L & W.H.O limit values (mg/L) \\
\hline Flourides & $1.65 \pm 0.01$ & $1.55 \pm 0.03$ & $1.24 \pm 0.01$ & 1.5 \\
\hline Sulfates & $415 \pm 0.04$ & $85.5 \pm 0.01$ & $158 \pm 0.02$ & 400 \\
\hline Sulphides & $0.01 \pm 0.00$ & $0.02 \pm 0.01$ & - & 0.05 \\
\hline Nitrates & $52.67 \pm 0.04$ & $1.15 \pm 0.01$ & $6.21 \pm 0.01$ & 10 \\
\hline Phosphates & $3.44 \pm 0.03$ & $0.02 \pm 0.00$ & $1.02 \pm 0.01$ & 0.5 \\
\hline Chlorides & $260.2 \pm 0.02$ & $158 \pm 0.02$ & $251 \pm 0.04$ & 250 \\
\hline Bicarbonates & $200.2 \pm 0.01$ & $62 \pm 0.02$ & $310 \pm 0.01$ & 300 \\
\hline
\end{tabular}

Table 3. Physical parameters and C.O.D results.

\begin{tabular}{llll}
\hline Parameters & C/Mbweni Zone & D/Mbovu- Amani Zone & M/Kwerekwe Zone \\
\hline $\mathrm{pH}$ & $8.4 \pm 0.5$ & $7.2 \pm 0.2$ & $7.7 \pm 0.3$ \\
Conductivity $(\mu \mathrm{s})$ & $2368 \pm 25.3$ & $1484 \pm 45.4$ & $1742 \pm 56.1$ \\
TDS & $1539 \pm 15$ & $1080 \pm 8$ & $940 \pm 11$ \\
Temperature & $23.5 \pm 2.1^{\circ} \mathrm{C}$ & $18.2 \pm 1.8^{\circ} \mathrm{C}$ & $20.5 \pm 1.5^{\circ} \mathrm{C}$ \\
Turbidity & $3.8 \pm 0.3$ & $2.5 \pm 0.4$ & $3.2 \pm 0.2$ \\
C.O.D & $305.3 \pm 0.4 \mathrm{mg} / \mathrm{L}$ & $189 \pm 0.5 \mathrm{mg} / \mathrm{L}$ & $244.6 \pm 0.2 \mathrm{mg} / \mathrm{L}$ \\
\hline
\end{tabular}

The tables 4 ( $a$ and $b$ ) shows the comparative values of hardness parameters for these raw groundwaters with respect to the standard values.

Table 4. The Standards for Water Hardness by Water Quality Association (WQA).

\begin{tabular}{llllll}
\hline Hardness Level & Soft & Slightly Hard & Moderately Hard & Hard & Very Hard \\
\hline $\mathrm{mg} / \mathrm{L}$ or $\mathrm{ppm}$ & Less than 17.1 & 17.1 to 60 & 60 to 120 & 120 to 180 \\
\hline
\end{tabular}

Table 5. Experimental results of Hardness from the three zones.

\begin{tabular}{llll}
\hline Parameter & C/Mbweni Zone & M/Kwerekwe Zone & D/Mbovu-Zone \\
\hline Hardness $(\mathrm{mg} / \mathrm{L})$ & $158.7 \pm 5$ & $115.4 \pm 4$ & $73.5 \pm 5$ \\
\hline
\end{tabular}

The GC/MS qualitative results of these raw groundwaters from the three zones are shown in the tables 6-8.

Table 6. The GC/MS qualitative results of Chukwani/Mbweni Zone.

\begin{tabular}{|c|c|c|c|c|}
\hline $\mathbf{S} / \mathbf{N}$ & NAME OF THE COMPOUND & R. TIME & AREA & HEIGHT \\
\hline 1 & Phenol, 2,4-bis(1,1-dimethylethyl)- & 7.132 & 676173 & 381479 \\
\hline 2 & Phthalic acid, 2,7-dimethyloct-7-en-5-yn-4-yl isobutyl ester & 9.811 & 137253 & 103904 \\
\hline 3 & Terpinylformate, & 10.047 & 64633 & 30118 \\
\hline 4 & Dietilphthalate & 3.214 & 3456 & 10989 \\
\hline 5 & Dichloroacetic acid, heptadecyl ester & 10.61 & 8619 & 57753 \\
\hline 6 & 5-ethenyl-5-methyl-2,4-oxazolidinedione & 7.745 & 173235 & 116723 \\
\hline 8 & 1,1-dichloro-1-nitroethane & 4.472 & 9455 & 30678 \\
\hline 9 & 1,4-dichlorobencene & 4.012 & 9276 & 30761 \\
\hline 10 & 9-t-Butyltricyclo[4.2.1.1(2,5)]decane-9,10-diol & 13.448 & 130563 & 77010 \\
\hline 11 & Bromoacetic acid, octadecyl ester & 15.021 & 67343 & 39101 \\
\hline 12 & $17 \alpha$-ethinylestradiol & 5.654 & 5687 & 3482 \\
\hline
\end{tabular}


Table 7. The GC/MS qualitative results of DarajaMbovu-Amani Zone.

\begin{tabular}{|c|c|c|c|c|}
\hline $\mathbf{S} / \mathbf{N}$ & NAME OF THE COMPOUND & R. TIME & AREA & HEIGHT \\
\hline 1 & Trifluoroacetic acid, pentadecyl ester & 9.25 & 88293 & 62661 \\
\hline 2 & 1,2-Benzenedicarboxylic acid, bis(2-methylpropyl) ester & 9.806 & 59981 & 43322 \\
\hline 3 & Dibutyl phthalate & 10.123 & 113881 & 85214 \\
\hline 4 & Methyl phthalate & 10.438 & 307779 & 216451 \\
\hline 5 & Dichloroacetic acid, heptadecyl ester & 10.604 & 105680 & 73113 \\
\hline 6 & Oxirane, tetradecyl- & 11.209 & 99994 & 12840 \\
\hline 7 & 5-methyl-2-hexanone & 7.543 & 3214 & 4011 \\
\hline 9 & dietilphthalate, 1,2,4-trimethylbenzene & 5.671 & 55324 & 4262 \\
\hline 10 & Oxirane, hexadecyl- & 17.967 & 356564 & 55822 \\
\hline 11 & 1,2,3,4-tetrahydronaphtalene & 4.967 & 22403 & 5948 \\
\hline 12 & Diethylstilbestrol & 5.81 & 2401 & 2211 \\
\hline
\end{tabular}

Table 8. The GC/MC qualitative results of $M /$ Kwerekwe-Zone.

\begin{tabular}{|c|c|c|c|c|}
\hline $\mathbf{S} / \mathbf{N}$ & NAME OF THE COMPOUND & R. TIME & AREA & HEIGHT \\
\hline 1 & Trifluoroacetic acid, pentadecyl ester & 7.741 & 80570 & 49520 \\
\hline 2 & Dichloroacetic acid, heptadecyl ester & 9.249 & 103400 & 71613 \\
\hline 3 & 1,2-Benzenedicarboxylic acid, bis(2-methylpropyl) ester & 9.805 & 65115 & 46106 \\
\hline 4 & Dibutyl phthalate & 10.122 & 124460 & 92870 \\
\hline 5 & Dichloroacetic acid, heptadecyl ester & 10.604 & 113311 & 80208 \\
\hline 6 & [1,1'-Biphenyl]-2,3'-diol, 3,4',5,6'-tetrakis(1,1-dimethylethyl)- & 12.83 & 28705 & 20460 \\
\hline 7 & 3-Chloropropionic acid, heptadecyl ester & 13.173 & 3000 & 1964 \\
\hline 8 & 2- Bromopropionic acid, octyl ester & 13.557 & 13839 & 9028 \\
\hline 9 & Bis(2-ethylhexyl) phthalate & 13.815 & 350632 & 238192 \\
\hline 10 & Sulfurous acid, octadecyl 2-propyl ester & 14.534 & 5669 & 3981 \\
\hline 11 & Vinclozolin & 4.875 & 4332 & 1895 \\
\hline 12 & Citalopram & 4.789 & 4876 & 2113 \\
\hline
\end{tabular}

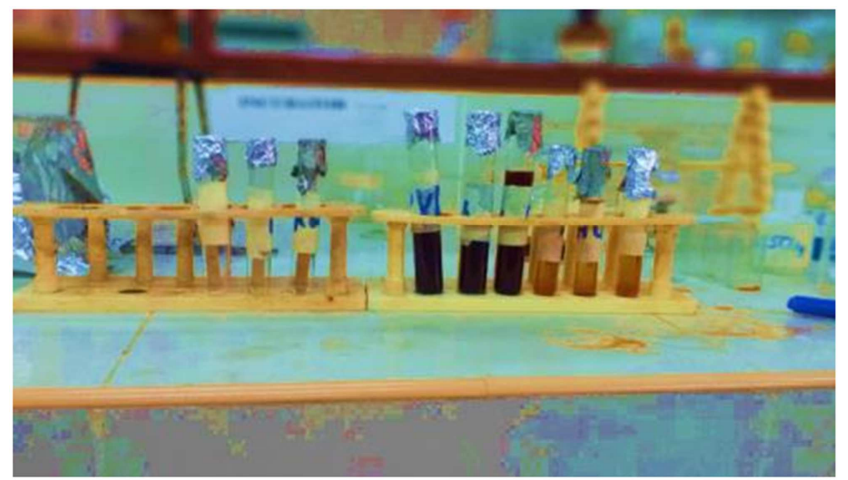

Microbial concentration coloration of MPN test $\left(10 \mathrm{~cm}^{3}, 0.1 \mathrm{~cm}^{3}\right.$ and $0.001 \mathrm{~cm}^{3}$ )

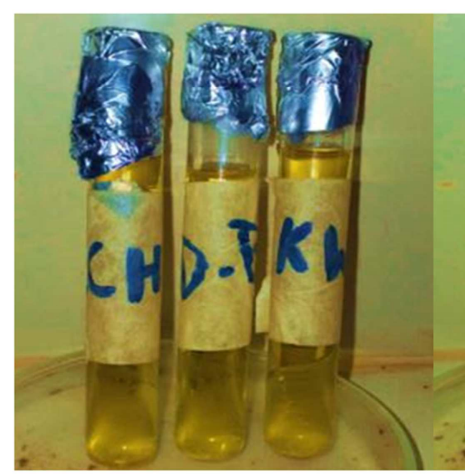

Sample $10 \mathrm{~cm}^{3}$

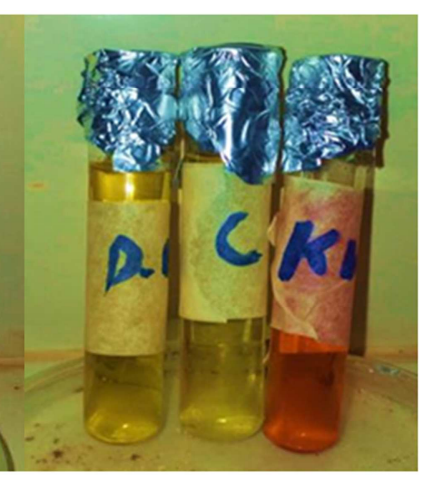

Sample $0.01 \mathrm{~cm}^{3}$
Figure 1. Shows photo-shot results for MPN test at different concentrations.

The table 6 Showing statistical results from figure 1 of 9 tubes at each of $0.1,0.01$ and 0.001 ginocula, the MPNs and $95 \%$ confidence interval.

Table 9. Microbial contamination statistical results.

\begin{tabular}{llllll}
\hline \multicolumn{2}{l}{ Pos. tubes } & & \multirow{2}{*}{ MPN/g } & \multicolumn{2}{l}{ Conf. lim. } \\
\cline { 1 - 2 } \cline { 5 - 6 } $\mathbf{n n n n}$ & $\mathbf{0 . 0 1}$ & $\mathbf{0 . 0 0 1}$ & & Low & High \\
\hline 3 & 3 & 0 & 280 & 100 & 710 \\
3 & 3 & 2 & 430 & 100 & 1100 \\
3 & 3 & 3 & 430 & 150 & 1100 \\
\hline
\end{tabular}

\section{Discussion}

The quality of drinking water is a powerful environmental determinant of health which must be noted as a basic human need [84, 58]. The experimental data obtained shows disparities in anions and cations concentrations in addition to the hydrocarbons derivatives realized from these groundwaters against the WHO drinking water quality standards. The average concentration of calcium was found to be more in $\mathrm{M} / \mathrm{kwerekwe}$ ground water and above the WHO limit incomparable to other zones. The presence of both magnesium and calcium sulfates and /or chlorides in water contributes to the water hardness with $\mathrm{C} / \mathrm{Mbweni}$ groundwaters having the highest value (Table 5). All these groundwaters are not soft (Table 5) comparing with the standards (Table 4) therefore requires softening. The existence of calcium and magnesium may be attributed to the natural occurrence of gypsum which is abundant within the Island. It has also been realized that most mineralization of infiltrating low-mineral rainwater occurs during recharge when carbonate dissolution and 
silicate weathering occurs leading to increased levels of Ca, $\mathrm{Mg}, \mathrm{Na}$ and $\mathrm{K}[14,69]$. From health perspective, hardness upto $500 \mathrm{mg} / \mathrm{L}$ is safe but more than this cause laxative effects [59]. Magnesium, though within the range of WHO drinking standards (Table 1) is a dietary mineral for humans and a very important ingredient for many enzymes in our body including DNA replication however too much overdose leads to nerve depression, urine retention, cardiac arrest, low blood pressure, personality changes, vomit and diarrhea [88]. But Lower magnesium intake is associated with worse knee pain and function in radiographic knee osteoarthritis, especially among individuals with low fiber intake [71, 17]. Excess calcium reacts with the naturally occurring pyrophosphates chemical within our bodies to form calcium pyrophosphate dihydrate (CPPD) crystals which collects in the cartilage causing joints swelling, pains in knees, wrist, ankles, shoulders and other joints particularly to age sets above fifty years. This types of arthritis disease known as pseudogout [78, 65].

No Zinc was detected in all the waters therefore health risks associated with Zinc such as skin irritation, pancreas damage, anemia, etc may be tied to a different cause. Cadmium, though occurs in small concentrations $(0.001-$ $0.002 \mathrm{mg} / \mathrm{L}$ ) below the recommended limit of $0.003 \mathrm{mg} / \mathrm{L}$, a lifetime body accumulation at levels exceeding $0.005 \mathrm{mg} / \mathrm{L}$ can cause renal failure, liver, sensory disturbance, convulsions, lung damage, shock, salivation, bone and blood damage [62]. The major sources of cadmium are decayed debris which had accumulated then solidified into rocks and underground mineralization via bacterial process then finally reach into groundwater bodies [27]. Chromium (III) with accumulation of $0.1 \mathrm{mg} / \mathrm{L}$ causes similar effects as cadmium in addition to affecting internal hemorrhage and respiratory disorders while chromium (IV) can cause dermatitis and ulceration [75]. It is quite interesting that lead, which may have originated mainly from household faucets, dumped solder joints, a concentration of $0.24 \mathrm{mg} / \mathrm{L}$ has been realized from D/Mbovu- Amani Zone groundwaters against the recommended $0.01 \mathrm{mg} / \mathrm{L}$. It is highly toxic even at relatively low concentrations $[15,4]$. Its accumulation in human body over some time causes serious damage to brain, kidney, nervous and red blood cells. For infants, large amount of lead can cause delays in physical and mental development since it attacks brain and the central nervous system [89]. Generally, selenium is found in traces in the soils and its accumulation leads to foul breath, vomiting and diarrhea, irritability, fatigue, hypertension [42]. Naturally, sedimentary aquifers are found to contain excessive arsenic levels and fluoride levels in addition to Calcium, Magnesium, iron, sodium, and Potassium [14] but are often associated with the carcinogen arsenic since its harmfulness outweighs the benefits of the salubrious minerals. Studies have shown that consumption of arsenic (a natural component of earthcrust) over periods of 5 to 25 years its inorganic form leads to cancer and skin lesion, negative impacts on cognitive development and increased deaths in young adults while its organic form rarely it does not generally accumulate in the body [89, 79]. Aluminum concentration detected though decimal $<0.2 \mathrm{mg} / \mathrm{L}$, however, prolonged intake leads to alzheimer's and parkinson's disease, senility and pre-senile dementia [89]. Its anthropogenic release in waters is most probably from wastes water effluents and solid wastes containing food cans, cookware [6, $16,26]$. Indeed, there is a lot of imported kitchenware materials, canned food and beverages containers made of aluminum found within the Island and their disposal system is worrying. These heavy metals (atomic weight lies between 63.5 and 200.5, sp. gr. > 4.0) Al, $\mathrm{Pb}, \mathrm{Cd}$ and As do exist in these groundwater in colloidal, particulate and dissolved phases $[34,2]$ with their occurrence attributed to natural origin (e.g. eroded minerals within sediments, leaching of ore deposits and volcanism extruded products) or of anthropogenic origin (i.e. solid waste disposal, industrial or domestic effluents, harbour channel dredging) [51]. The concentrations of sodium are not very worrying though excessive sodium in drinking water is also an issue when combined with the normal dietary level intakes, may lead to hypertension and cardiometabolic diseases particularly in pregnant women $[14,5]$ and among infants it causes hypernatraemia and serious neurological damage [63]. Too muck potassium intake may result into a significant health effects in people with kidney disease or other conditions such as heart disease, coronary artery disease, hypertension, diabetes and adrenal insufficiency [46] while no significant health effects associated with calcium have been reported at those found concentrations.

The high values of C.O.D reported in table 3 indicates the levels of organic pollutants into the groundwater system. These values ascertain the existence of poor waste disposal systems, infiltration of domestic sewer systems into the groundwater basin, landfill leachates and the intrusion of fertilizers, pesticides [44, 34]. C/Mbweni zone has the highest value due to the existence fertilized irrigated small vegetable farms in addition to the poor disposal system which includes wastes from households (domestic wastes), salons, landfills leachetes, etc.

Organic compounds such as phthalates, oxiranes, biphenyls, carboxylic acids derivatives dichloronitroethanes, phenolic derivatives, diethlystilbestrol, etc. used as plasticizers, fungicides, detergents, pesticides, fertilizers, contraception/ personal care products, and cosmetic formulations, are grouped as endocrine disruptive chemical. The qualitative assessment using the GC-MS spectroscopic machine revealed the presence of these EDC organic compounds in every groundwaters (Tables 6, 7, 8). The existence of these EDC elements is evident by the high C.O.D values (Table 3). For example, in table 6, the phthalates derivative compounds, Vinclozolin compounds such as 5-ethenyl-5-methyl-2,4-oxazolidinedione, 1,4dichlorobencene, 1,1-dichloro-1-nitroethane, are EDC associated with fertilizers, pesticides, etc. Their existence is associated with small irrigated artificially fertilized vegetable farms within $\mathrm{C} / \mathrm{Mbweni}$ zone. Compound such as $17 \alpha-$ ethinylestradiol, diethylstilbestrol is associated with personal health care products. The lethal EDC elements such as 
phthalates, esters, biphenyl and ketonic derivatives apart from being components of plasticizers, fungicides, detergents, flavoring and essence components, they are also associated more with effluents from personal health care and cosmetic application industry which indeed is a rampant business due to the influence of Unguja Island social setups. These infiltrates into groundwater system due to poor waste disposal system, and poor sewage disposal system found within the residential area. The C/Mbweni Zone and D/Mbovu- Amani Zone has more concentrations of these EDC contaminants since these populated residential areas have a lot of beautification centers (Salons) in addition to contaminants from domestic waste disposal. In these regions Cosmetics shops are on the increase implying increase in cosmetics products consumptions consequently cosmetics and personal care products effluents are also on the rise. Pesticides such as 1,2,3,4-tetrahydronaphtalene, 1,4dichlorobencene, etc has also been detected in D/MbovuAmani and $\mathrm{C} /$ Mbweni groundwaters incomparable to $\mathrm{M} /$ kwerekwe waters. These severe water contaminants/ infiltrates into ground water systems and are resistant to natural degradation $[55,54,26,23]$. Studies have shown that EDC's have serious health consequences such as brain disorders, pubertal timing variations, ovulatory disorders, prostrate and breast cancer, unusual sexual misbehavior, male infertility, immune abnormality, blue baby syndrome, hypospadias, reduced anogenital distance leading to UTI cases particularly in women, cryptorchidism, low IQs, structural anomalies, disrupted hypothalamic estrogenic receptor distribution, alteration of nitric oxide syntheses signaling, affectations of human immune function, and disrupted behavior in children associated with early life BPA exposure, especially in girls, oligospermia to mention but afew $[45,77,24]$.

The concentration of flouride ranges from 1.65 to 1.24 $\mathrm{mg} / \mathrm{L}$. These concentrations cannot lead to skeletal fluorosis which flourishes with concentrations between $3-6 \mathrm{mg} / \mathrm{L}$ [86, 72, 67, 19] but can cause slight dental fluorosis [3]. Low concentrations of fluoride have been considered beneficial to prevent dental carries [86, 49, 61]. The nitrate concentrations ranges from $53.7-1.15 \mathrm{mg} / \mathrm{L}$ with $\mathrm{C} /$ Mbweni zone having above the WHO mark of $10 \mathrm{mg} / \mathrm{L}$. The main source is likely from fertilizers used in the vegetable farms [25], nitrogen fixation from atmosphere by legumes, bacteria, poor waste water disposal system and sludge. The $\mathrm{M} / \mathrm{kwerekwe}$ and $\mathrm{D} / \mathrm{Mbovu}$ - Amani zones do not have irrigated small farms consequently nitrate existence in groundwater may be attributed to poor waste water disposal system and natural occurrence. Above 40 $\mathrm{mg} / \mathrm{L}$ is known to cause blue baby syndrome or methemoglobinemia in children [67]. Studies have revealed that nitrates cannot be removed from drinking water by boiling [70] therefore it easily finds its way into the human body unless removed using alternative purification methods. The high chloride levels (260 and $251 \mathrm{mg} / \mathrm{L})$ may be an indicator of pollution by sewage or irrigation leachates [66]. The contents of bicarbonates and carbonates have no known adverse health effects but their dominant concentrations suggest water - rocks interactions. Apart from anthropogenic sources such as gypsum, microbial degradation of organic matter which releases phosphorous in phosphate forms and domestic sewage, excess phosphates in $\mathrm{C} / \mathrm{Mbweni}$ zone ground waters may be attributed to excess use of fertilizers in those nuclear small farms [25]. Since phosphates are not very mobile in soil, there are transported easily by percolating waters into the groundwater basin and such quantities reported of 3.44 $\mathrm{mg} / \mathrm{L}$ are not very harmful to man [56]. The sulfate concentration is found to range from 85 to $415 \mathrm{mg} / \mathrm{L}$. Drinking waters with sulphate concentrations above 200 $\mathrm{mg} / \mathrm{l}$ like C/Mbweni Zone waters may lead to gastrointestinal irritation and bowel discomfort [70, 87]. This high value most likely is associated with effluents from infiltration from sulphate based fertilizers used in the farms [25] in addition to wastewater discharges particularly from households. M/kwerekwe zone has the largest food market in Unguja Island, large waste water disposal pond and several waste damps. Most likely the infiltration of these landfill leachates [26] in addition to weathering of geomorphological structures/mineral into the groundwater basin leads to the stated sulfated concentration.

From the cation and anion concentrations, three major likely hydrochemical facies are $\mathrm{Ca}-\mathrm{Cl}$, mixed $\mathrm{Ca}-\mathrm{Mg}-\mathrm{Cl}$ and $\mathrm{Na}-\mathrm{Cl}$ meaning that the samples are saline with low to high sodium hazard. This signifies that these regions are to some appreciable extent affected by saltwater contamination due to seawater intrusion [37], domestic sewage and saltpan deposits. C/Mbweni zone is leading since it is closer to the sea than the rest. These aspects do confirm why we have high $\mathrm{EC}$, TDS and Chloride values particularly in the C/Mbweni zone. This too concurs well with the $\mathrm{pH}$ values which have been found to fall within the W.H.O. range but on the higher side indicating these groundwaters are slightly alkaline. This also commensurate well with the moderate hardness found and supports the problems of variable tastes, odour and colour [15] experienced by locals. Studies have shown that temperatures above $15^{\circ} \mathrm{C}$ enhances the growth of nuisance organisms hence concurs well with the microbial contamination levels reported (Table 9). The microbial contamination is so much attributed to poor sanitations signifying fecal contamination due to poor sewage disposal systems and seepages from various wastes dumps acting as vehicles for microbes into groundwater basins [11, 35]. The presences of microbial contamination is also supported by the high $\mathrm{pH}$ values or alkalinity which is found to decrease the germicidal potential of chlorine [88]. The conductivity ranges from 1429 - 2393.3 $\mu$ s above the WHO limits with C/Mbweni zone leading the track. These parameter depends on presences of total dissolved ionic components in water, their total concentrations, mobility, valence, relative concentration and temperature $[58,91]$. High concentrations of $\mathrm{Na}, \mathrm{K} . \mathrm{Mg}$ and $\mathrm{Ca}$ could be the main game changer behind conductivity levels among these zones. The values above the WHO limits cause stomach rambles and diarrhea [87], and also is an indicator for TDS values. Normally TDS indicates the sum of 
all components dissolved in water e.g. $\mathrm{K}^{+}, \mathrm{Na}^{+}, \mathrm{Ca}^{2+}, \mathrm{Mg}^{2+}$, $\mathrm{SO}_{4}^{2-}, \mathrm{Cl}^{-}$, etc. $\mathrm{C} / \mathrm{Mbweni}$ Zone has the highest of around 1539 'mg/L far beyond the recommended limits (Table 3). This may be attributed to the agricultural activities, low lying topographical position within the hydrological zoning and its closeness to the sea. Waters with high dissolved solids is known to cause impairment of physiological processes in the human, gastrointestinal irritation [36]. Despite of complains of gastrointestinal irritations, stomach rambles, etc. upto date there is no health based guidelines for TDS in Zanzibar.

Groundwaters normally have low turbidity because of the natural filtration that occurs as they penetrate through the soil [82]. This is evident from the low values of less than $3 \mathrm{NTU}$ but this does not signify that during treatment and purification we should not filter the water. Likewise, the appearance, taste, colour and odour do not really tell if the water is safe to drink.

From Ministry of Health (Revolutionary Government of Zanzibar) (2020 - 2019) bulletin and informative, cases such as, among others, brain disorders, UTIs, ovulatory disorders, low IQs, blue baby syndromes, immune abnormalities, arthritis and joint pains, gastrointestinal irritation and bowel discomfort, skin diseases, disrupted behavior in children associated with early life BPA exposure, kidney problems, sensory issues, fatigue, hypertension, etc. are on the rise but the question is, should we tie them on these contaminants' effects? These negative impacts of contaminated groundwater on human health are chronic and at times hard to diagnose [13] apart from waterborne diseases such as cholera, typhoid fever, etc. Therefore, more research needs to be done to ascertain the connection. The composite overall result shows the ingestion of these cations, anions, EDC elements and the nature of these ground waters as drinking water indicates that the total health risks are beyond the US EPA acceptable level of $10^{-6}$ per year [88] for consumption of groundwater sourced from three zones. This is worrying and a potential health risks to vulnerable individuals with the health risks to children higher than the risks to adults.

\section{Conclusion}

From the above results, it confirms that these groundwaters are contaminated, infected and not potable. These groundwaters requires purification and treatment to make them potable and palatable rather than relying on the conventional treatment of boiling which either destroys or deactivate microorganisms. To improve on these raw groundwaters suitability for drinking, it requires treating these waters through screening, sedimentation and filtration or aeration, to reduce and eliminate any form of contaminants before physical-chemical and microbial treatment for dissolved constituents and microbes respectively in order to conform with the latest drinking water quality standards laid by the World Health Organization (WHO).

\section{Recommendations}

When WHO standard or guideline is exceeded proper action is required. The government needs to initiate and improve on the existing Environmental Protection policy acts on the sources of these haphazard contaminants, decimalize these nuclear/small vegetable farms within residential areas and regulate on the type of fertilizers, personal health care products and cosmetics suitable for use. The mass should be made aware on the consequences of contaminants. There is a need for exponential increase for suitable groundwater evaluation of groundwaters quality with the aim of safeguard public health and protecting the groundwater resources, and a proper coordination of health records on health issues associated with contaminant be well documented. This study also recommends medical hydrogeology framework may help in regionalizing water quality. This study proposes exponential hydrogeochemical evaluation of groundwater by using soft computing techniques or models which are accurate and reliable such as Piper plots and Durov plots suitable for demonstrating large amount of data and defining major trends of pollutants concentrations consequently leading to formulating suitable water treatment. The soil Permeability index and Water quality index analyses should be done in order to give the true status of the quality of groundwater resources for drinking purposes. Principal Component and Cluster water analyses should also be encouraged and latest methods for detecting and tracking the movement of groundwater contaminants are indeed appreciated. Radiochemical multielements analysis is recommended since decimal concentration of titanium ores have been identified along the ocean shores. There is also the need for case studies and remedial actions in controlling groundwater from natural sources, effects of groundwater contamination on the abiotic environment and novel techniques for assessing risks to human populations consuming these contaminated groundwaters.

\section{Funding Statement}

The authors are grateful to Sumait University for partly funding this work.

\section{Competing Interest}

The authors have declared that there are no competing interests exist.

\section{Acknowledgements}

Many thanks goes to Dr. Sunghwa Fortunatus, the chief laboratory scientist and Pius Matiku both of Chemistry department, University of Dar es salaam for their guidance, support and spectroscopic knowledge, and not forgetting laboratory services offered by Kenya Bureau of Standards, Zanzibar Drop Water Company, Zanzibar Bureau of Standards and Government of Zanzibar Chemist, and Ministry of Health-Zanzibar for relevant data acquisition. 


\section{References}

[1] African Development Bank (AFDB),(2020); Tanzania: Zanzibar's urban residents have improved access to water and sanitation with African Development Bank support, Report October, 2020.

[2] Adepoju-Bello, A. A., Ojomolade, O. O., Ayoola, G. A. and Coker, H. B. (2009); Quantitative analysis of some toxic metals in domestic water obtained from Lagos metropolis, The Nig. J. Pharm. 42 (1): 57-60.

[3] Aldrees, A. M. and AL-Manea, S. M. (2010); Fluoride content of bottled drinking waters available in Riyadh, Saudi Arabia, Saudi Dent. J, 22 189-193.

[4] Alemu, T., Mulugeta, E., Tadese M. (2017); Determination of physicochemical parameters of "Hora" natural mineral water and soil in Senkele Kebele, Oromia Region, Ethiopia, Cogent $\begin{array}{llll}\text { chem., } & 3 & (1): & \end{array}$ https://doi.org/10.1080/23312009.2017.1354800.

[5] Alsulaili, A., Al-Harbi, M., Al-Tawari, K. (2015); Physical and chemical characteristics of drinking water quality in Kuwait: tap vs. bottled water, J Eng Res, 3 (1): 2. https://doi.org/10.7603/s40632-015-0002-y.

[6] Angela, M. and Renée, S. (2020); Recycled aluminum cooking pots: A growing public health concern in poorly resourced countries, BMC Public Health, vol 20, Article number: 1411.

[7] APHA, (1998); Standard Methods for the Examination of Water and Wastewater, American Public Health Association, Washington, DC.

[8] Arenes, A. D. and Huertas, J. F. (1986); Hydrology and Water Balance of Small Islands, A review of existing knowledge, UNESCO/IHP.

[9] Basu, A., Saha, D., Saha, R., Ghosh, T., Saha, B. (2014); A review on sources, toxicity and remediation technologies for removing arsenic from drinking water, Res Chem Intermediation, 40: 447-485.

[10] Belghith, N. B. H. and De Boisseson, P. M. A. (.2017); Zanzibar poverty assessment: World Bank Group. Washington, D.C. http://documents.worldbank.org/curated/en/77805150902169993 7.

[11] Ben Maamar, S., Aquilina, L., Quaiser, A., Pauwels, H., Michon-Coudouel, S., Vergnaud-Ayraud, V., Labasque, T., Roques, C., Abbott, B. W., Dufresne, A. (2015); Groundwater isolation governs chemistry and microbial community structure along hydrologic flowpaths, Front Microbiol, 6: 1457.

[12] Berman, E. (1980). Toxic metals and their analysis, Philadelpia PA, Hayden and son limited, London.

[13] Chakraborti, D., Rahman, M. M., Mukherjee, A., Alauddin, M., Hassan, M., Dutta, R. N., Pati, S., Mukherjee, S. C., Roy, S., Quamruzzman, Q., Rahman, M., Islam. T., Sorif, S., Selim, M. d., Islam, M. R., Hossain, M. M. (2015). Groundwater arsenic contamination in Bangladesh-21 years of research. $J$ Trace Elem Med Biol 31: 237-248.

[14] Chihurumnanya, B. N, Mohammad, A. H., Md Atikul, I. and Ashraf, D. (2020); Groundwater Constituents and Trace
Elements in the Basement Aquifers of Africa and Sedimentary Aquifers of Asia: Medical Hydrogeology of Drinking Water Minerals and Toxicants: Earth Systems and Environment, volume 4, pages 369-384.

[15] Chinedu, S. N., Nwinyi, O., Oluwadamisi, A. Y. and Eze, V. N. (2011); Assessment of water quality in Canaanland, Ota, Southwest Nigeria. Agric Biol J N Am 2 (4): 577-583. https://doi.org/10.5251/abjna.2011.2.4.577.583.

[16] Daria Popugaeva (2019); Analysis and Control of Aluminum Concentration in Groundwater: Mathematical Modelling and Laboratory Study, The University of Western Ontario, vol 6: 45.

[17] Davis, J., Eaton, CB., Lo, GH., Lu, B., Price, LL., McAlindon, TE., Barbe, MF., Driban, JB. Knee symptoms among adults at risk for accelerated knee osteoarthritis: data from the Osteoarthritis Initiative, Clin Rheumatol, (2017) 36 (5): 10831089. PMID: 28188391 doi: 10.1007/s10067-017-3564-2.

[18] Duk, H. L. (2018); Evidence of the Possible Harm of Endocrine-Disrupting Chemicals in Humans: Ongoing Debates and Key Issues, Korea (South): Korean Endocrine Society, Endocrinology and metabolism (Seoul), 2018-03, Vol 33 (1), p. 44-52.

[19] Dunne, K. and Verrell, P. (2011); Acute effect of exposure to sodium fluoride on the red compost earthworm Eisenia fetida: Lethality and avoidance behavior. Fluoride, 44 210-214.

[20] Edmunds, W. M. and Smedley, P. L. (1996); Groundwater geochemistry and health: an overview. Geol Soc Lond Spec Publ 113: 91-105.

[21] Elango, L. and Kannan, R. (2007); Chapter 11, Rock-water interaction and its control on chemical composition of groundwater. In: Sarkar D, Datta R, Hannigan R (eds), Developments in environmental science, Elsevier, Amsterdam, pp 229-243.

[22] Erban, L. E., Gorelick, S. M., Zebker, H. A. and Fendorf S. (2013); Release of arsenic to deep groundwater in the Mekong Delta, Vietnam, linked to pumping-induced land subsidence. Proc Natl Acad Sci 110: 13751-13756.

[23] Erikson, K. M., Dorman, D.. C, Lash,. L H. and Aschner, M. (2005). Persistent alterations in biomarkers of oxidative stress resulting from combined in utero and neonatal manganese inhalation. Biol Trace Elem Res 104 (2): 151-163. https://doi.org/10.1385/bter:104:2:151.

[24] Evanthia, Diamanti-Kandarakis, Jean-Pierre, B., Linda, C., Giudice, R H, Gail S. P., Ana M. S., Thomas Z. R., Andrea, C. G. (2009); Endocrine-Disrupting Chemicals: An Endocrine Society Scientific Statement. Endocrine Reviews, Vol 30, Issue 4, 293-342, https://doi.org/10.1210/er.2009-0002.

[25] FAO (2016). AQUASTAT, http://www.fao.org/nr/water/aquastat/countries regions/GHA/. Food and Agriculture Organization of the United Nations (FAO).

[26] Fatta, D., Papadopoulos, A. and Loizidou, M. (1999); A study on the landfill leachate and its impact on the groundwater quality of the greater area, Environ. Geochem. Health, 21, 175-190.

[27] Gbadebo, A. M., Ayedun, H. and Moses, A. I. (2015); Hydrogeochemical assessment of groundwater in Iwo, Ikonofin ad Ife-odan, Osun and Oyo states, southwest Nigeria, Environ Earth Sci 73: 3633 - 3642. 
[28] Gössling, S. (2001); The consequences of tourism for sustainable water use on a tropical island: Zanzibar, Tanzania. J Environ Manag 61: 179-191.

[29] Halcrow, W. (1994); Zanzibar Hydrogeological Survey Netherlands Institute of Ecology, Centre for Esturarine and Coastal Ecology, Netherlands.

[30] Hansson, E. (2010); Groundwater on Zanzibar-use and contaminants. University of Goteborg, Sweden.

[31] Hassan M. N., Theng L. C., Allgaier G. and Stegmann R., (2006); Landfilling. In solid waste management in Asia. An e-book of teaching and training modules for higher education in the waste management sector, The TUHH Hamburg University of Technology, Hamburg, Germany. pp. 165-185.

[32] He, X., Li, P., Wu, J., Wei, M., Ren, X. and Wang, D. (2020a); Poor groundwater quality and high potential health risks in the Datong Basin, northern China: research from published dat, Environ Geo chem Health. doi.org/10.1007/s10653-02000520-7.

[33] Hoque, M. A., Burgess, W. G. and Ahmed, K. M. (2017); Integration of aquifer geology, groundwater flow and arsenic distribution in deltaic aquifers-a unifying concept, Hydrol Process 31: 2095-2109.

[34] Hossain, M. L., Das, S. R. and Hossain, M. K. (2014); Impact of landfill leachate on surface and ground water quality, $J$ Environ Sci Technol, 7: 337-346. http//doi.org/10.3923/jest.2014.337.346.

[35] Hudak, P. F. (2005); Sensitivity of groundwater monitoring networks to contaminant source width for various seepage velocities, Water Resour. Res., 41, W08501, doi: 10.1029/2005WR003968.

[36] Jagadeeswari, B. and Ramesh, k. (2012). Water Quality Index For Assessment Of Water Quality In South Chennai Coastal Aquifer, Tamil Nadu, India, International Journal of Chem Tech Research, Vol. 4, No. 4, pp 1582-1588.

[37] Jamshidzadeh, Z. and Mirbagheri, S. A. (2011); Evaluation of groundwater quantity and quality in the Kashan Basin, Central Iran. Desalination, 270: 23-30.

[38] Japan International Cooperation Agency (JICA), NJS consultants, Yokohama Water Company (YWC), ZAWA (2017); Preparatory Survey on Zanzibar Urban Water Distribution Facilities Improvement Project in United Republic of Tanzania, Final Report, 2017.

[39] Johnson, J. (1983); Groundwater Review, Zanzibar Island. FAO, Rome, Italy.

[40] Kahn L. G., Philippat, C., Nakayama S., F., Slama R. and Trasande L. (2020); Endocrine-disrupting chemicals: implications for human health, The Lancet Diabetes \& Endocrinology, Volume 8, Issue 8, $703-718$.

[41] Karolina, N., Ewa, J. and Wioletta, R-W (2019); Immunomodulatory effects of synthetic endocrine disrupting chemicals on the development and functions of human immune cells, $J$ Environ Int, 125: 350-364, doi: 10.1016/j.envint.2019.01.078.

[42] Kern L. N. (2006); Evaluating selenium poisoning, Annals of Clinical and Laboratory Science, Volume 36 (4): 409-20.
[43] Kiptum, C. K. and Ndambuki, J. M. (2012); Well water contamination by pit latrines: a case study of Langas. Int $J$ Water Resour Environ Eng, 4: 35-43.

[44] Koda, E., Miszkowska, A. and Sieczka, A. (2017); Levels of Organic Pollution Indicators in Groundwater at the Old Landfill and Waste Management Site, Faculty of Civil and Environmental Engineering, Warsaw University of Life Sciences, Poland.

[45] La Merrill M. A., Vandenberg, L. N., Smith, M. T., Goodson, W., Browne, P., Patisaul, H. B., Guyton, K. Z., Kortenkamp, A., Cogliano, V. J., Woodruff, T. J., Rieswijk, T., Sone, H., Korach, K. S., Gore, A. C., Zeise, L. and Zoeller, R, T. (2020); Consensus on the key characteristics of endocrine-disrupting chemicals as a basis for hazard identification, Nature Reviews on Endocrinology, Vol 16, pages 45-57.

[46] Leurs, L. J., Schoutent, L. J., Mons, M. M., Goldbohm, R. A. and Van den Brandt, P. A. (2010); Relationship between tap water hardness, magnesium, and calcium concentration and mortality due to ischemic heart disease or stroke in the Netherlands. Environ Health Persp, 118 (3): 414-420. https://doi.org/10.1289/ehp.0900782.

[47] Li, P. (2020); To make the water safer, Expo Health, 12: 337 342 .

[48] Li, P. and Wu, J. (2019); Sustainable living with risks: meeting the challenges, Hum Ecol Risk Assess, 25: 1-10.

[49] Livia, M., Andaló T. and Jaime A. C. (2010). Fluoride: its role in dentistry, Cariology, Braz. oral res, 24 (suppl 1). https://doi.org/10.1590/S1806-83242010000500003.

[50] MacDonald, A. M., Davies, J. and Calow, R. C. (2008). African hydrogeology and rural water supply. In: Adelana S, MacDonald AM (eds),. Applied groundwater studies in Africa, CRC Press, London, p 22.

[51] Marcovecchio, J. E., S. E. Botte and Freije, R. H. (2007); Heavy Metals, Major Metals, Trace Elements. In: Handbook of Water Analysis. L. M. Nollet, (Ed.). $2^{\text {nd }}$ Edn. London: CRC Press, pp: 275-311.

[52] Moturi W. K., Tole M. P. \& Davies T. C.(2002); The contribution of drinking water towards dental fluorosis: a case study of Njoro Division, Nakuru District, Kenya, Environmental Geochemistry and Health, 24 (2), 123-130 doi: 10.1023/A:1014204700612.

[53] Murphy, L. Y. W., Vanessa C. and El-Nezami, H.(2021); Endocrine disrupting chemicals and breast cancer: a systematic review of epidemiological studies, Critical Reviews in Food Science and Nutrition, DOI: 10.1080/10408398.2021.1903382.

[54] Nag, S. K. and Suchetana, B. (2016); Groundwater quality and its suitability for irrigation and domestic purposes: a study in rajnagar block, Birbhum district, West Bengal India, $J$ Earth $S c i$ Clim Change, 7: 337. https://doi.org/10.4172/2157-7617.1000337.

[55] Ncube, M. and Taigbenu, A. (2006); The Institutional Challenge in the Implementation of Water Demand Management: A Case of the City of Bulawayo, Zimbabwe, IASTED International Conference, At: Gaborone, Botswana.

[56] Nieder R., Benbi, D. K and Reichl F. X. (2018) Reactive Water-Soluble Forms of Nitrogen and Phosphorus and Their Impacts on Environment and Human Health. In book: Soil Components and Human Health DOI: 10.1007/978-94-0241222-2_5. 
[57] Nriagu, J. O. and Pacyna, J. M. (1988); Quantitative assessment of worldwide contamination of air, water and soils by trace metals, Nature, 333 (6169), 134-139.

[58] Oyem, H., Oyem, I. M., Ezeweali, D. (2014); Temperature, $\mathrm{pH}$, Electrical Conductivity, Total Dissolved Solids and Chemical Oxygen Demand of Groundwater in BojiBojiAgbor/Owa Area and Immediate Suburbs, Research Journal of Environmental Sciences, 8 (8): 444-450. DOI: 10.3923/rjes.2014.444.450.

[59] Pallav, S. (2013); Potential Health Impacts of Hard Water, Int J Prev Med. 4 (8): 866-875.

[60] Pandey, H. K., Duggal, S. K. and Jamatia, A. (2016); Fluoride contamination of groundwater and its hydrological evolution in District Sonbhadra (U.P.) India, Proc Nat Acad Sci, India Sect A Phys Sci 86: 81-9.

[61] Poul, E. P. and Hiroshi, O.(2016); Prevention of dental caries through the use of fluoride - the WHO approach, Community Dental Health, 33, 66-68. doi: 10.1922/CDH.

[62] Proshad. R., Saifullsam, Md., Sayeed, T., Sujan, A., Khadka, S. and Idris A. M (2021); Potential toxic metals (PTMs) contamination in agricultural soils and foodstuffs with associated source identification and model uncertainty, Science of The Total Environment, Volume 789.1.

[63] Rahman A, Hashem A, Nur-A-Tomal S (2016) Potable water quality monitoring of primary schools in Magura district, Bangladesh: children's health risk assessment. Environ Monit Assess 188 (12): 680. https://doi.org/10.1007/s10661-016-5692-6

[64] Reynolds-Vargas, J., Fraile-Merino, J. and Hirata, R. (2006); Trends in nitrate concentrations and determination of its origin using stable isotopes $\left({ }^{18} \mathrm{O}\right.$ and $\left.{ }^{15} \mathrm{~N}\right)$ in groundwater of the western Central Valley, Costa Rica., Ambio J Hum Environ, 35: 229-236.

[65] Rosales -Alexander, J., Aznar, J. and Magro-Checa, C. Calcium pyrophosphate crystal deposition disease: diagnosis and treatment, Dovepress, (2014), Volume 6: $39-47$. https://doi.org/10.2147/OARRR.S39039

[66] Sarda P, Sadgir P (2015) Assessment of multi parameters of water quality in surface water bodies - a review. Int J Res Appl Sci Eng Technol 3 (8): 331-336.

[67] Sellami M, Riahi H, Maatallah K, Ferjani H, Bouaziz MC, Ladeb MF (2019) Skeletal fluorosis: don't miss the diagnosis! Skeletal Radiol. https://doi.org/10.1007/s00256-019-03302-0

[68] Shaghude, Y. W. and Wannas, K. O. (1998); Morphology and sediment distribution of the Zanzibar. Channel. Ambio, 27 (8): 729-733.

[69] Shaghude, Y. W. and Wannas, K. O. (1995); Sediment distribution and transport in the Zanzibar channel. Ambio, 24 (7-8): 519-522.

[70] Sharma, S \& Bhattacharya, A. (2016); Drinking water contamination and treatment techniques, Applied Water Science 7 (3). DOI: 10.1007/s13201-016-0455-7.

[71] Shmagel, A., Onizuka, N., Langsetmo, L., Vo. T., Foley, R., Ensrud, K. and Valen, P. Low magnesium intake is associated with increased knee pain in subjects with radiographic knee osteoarthritis: data from the Osteoarthritis Initiative. Osteoarthritis Cartilage. (2018), 26 (5): 651-658. PMID: 29454594. doi: 10.1016/j.joca.2018.02.002.
[72] Shruthi MN, Anil NS (2018) A comparative study of dental fluorosis and non-skeletal manifestations of fluorosis in areas with different water fluoride concentrations in rural Kolar. J Family Med Prim Care 7 (6): 1222-1228. https://doi.org/10.4103/jfmpc.jfmpc_72_18

[73] Su, Z., Wu, J., He, X. and Elumalai, V. (2020); Temporal changes of groundwater quality within the groundwater depression cone and prediction of confined groundwater salinity using Grey Markov model in Yinchuan area of northwest China, Expo Health, 12: 447-468.

[74] Subba, R. N, Ravindra, B. and Wu, J. (2020); Geochemical and health risk evaluation of fluoride rich groundwater in Sattenapalle Region, Guntur district, Andhra Pradesh, India, Hum Ecol Risk Assess, 26: 2316-2348.

[75] Susan, R S., Phillip, G. and Donald V. B. (2007); Dermatological toxicity of hexavalent chromium, Crit Rev Toxicol, 37 (5): 375-87. doi: 10.1080/10408440701266582.

[76] Tatti, F., Papini, M. P., Torretta, V., Mancini, G., Boni, M. R. and Viotti, P. (2019); Experimental and numerical evaluation of groundwater circulation wells as a remediation technology for persistent, low permeability contaminant source zones. $J$ Contam Hydrol, 222: 89-100.

[77] Telma, E., Alberto, A. P., Maria, G. C. (2019); Endocrine disrupting chemicals: Impact on human health, wildlife and the environment, science progress.

[78] Tim, P. and David, O. (2021). Arthritis Causes and Risks factors; What to know about Calcium Pyrophospate Crystals, Verywell health reviews, 2021, htpps://www.verywellhealth.com

[79] Tyler, C. R. and Allan A. M. (2014); The Effects of Arsenic Exposure on Neurological and Cognitive Dysfunction in Human and Rodent Studies: A Review, Curr Environ Health Rep, 1 (2): 132-147.

[80] UNDTCD (1987); Hydrogeological Map of Zanzibar Map NO. 3344, United Nations.

[81] UNDP (2020); Socio-Economic Impact assessment in Tanzania, Financing for Sustainable Development Report, https://www.undp.org > tanzania > docs > docs2020.

[82] Viessman, W. and Hammer, M. J. (2004); Water supply and Pollution control, pearson college div., $7^{\text {th }}$ Edition.

[83] Vishnu P. P, Sangam S., Saroj K. C, Futaba K., (2011); A framework for measuring groundwater sustainability, Environmental Science \& Policy, Volume 14, Issue 4, Pages 396-407.

[84] Wang, D., Wang, L., Yang, Q., Yu, K. and Ma, H. (2021); Hydrogeochemistry assessment of shallow groundwater and its health threat on human in northwestern Ordos basin, China, Arch Environ Contam Toxicol, 80 (1): 92-106. doi: 10.1007/s00244-020-00804-0.

[85] Welz, B.; Mores, S.; Carasek, E.; Vale, M.; Okruss, M. and Becker-Ross, H (2010); High resolution continuum source atomic and molecular: A review, Applied Spectroscopy Reviews, Vol. 45, No. 5, pp. 327-354.

[86] WHO (2006); Fluoride in Drinking-Water. WA Publishing, London.

[87] WHO (2011); Gastrointestinal Irritations, Stomach rambles, bowel discomforts Causes. 
[88] WHO (2016); Total health risks acceptable levels-US EPA.

[89] WHO (2019); Lead poisoning and health.

[90] Wright, E. P. (1992); The hydrogeology of crystalline basement aquifers in Africa. Geol Soc Lond Spec Publ 66: 1-27.
[91] Yilmaz, E. and Koc, C. (2014) Physically and Chemically Evaluation for the Water Quality Criteria in a Farm on Akcay. Journal of Water Resource and Protection, 6, 63-67. https://doi.org/10.4236/jwarp.2014.62010 